\title{
De Xeikon-beschikking van de Hoge Raad van 19 juli 2019: cassatie wegens vormverzuim
}

\author{
Mr.T. Drent $b^{*}$
}

\begin{abstract}
De Hoge Raad casseert bij beschikking van 19 juli 2019 een deel van de (tweede-fase)beschikking en de daarop volgende verbeteringsbeschikking van de Ondernemingskamer met betrekking tot de enquêteprocedure inzake Xeikon N.V., kort gezegd wegens vormverzuim door de Ondernemingskamer. Deze bijdrage bespreekt de beschikking en de gevolgen daarvan.
\end{abstract}

\section{Inleiding}

De hier te bespreken beschikking van de Hoge Raad betreft het voorlopig meest recente hoofdstuk in de sinds 2014 lopende enquêteprocedure inzake Xeikon N.V. (hierna: Xeikon). De Hoge Raad casseert bij beschikking van 19 juli $2019^{1}$ een deel van de (tweede-fase)beschikking ${ }^{2}$ en de daarop volgende verbeteringsbeschikking ${ }^{3}$ van de Ondernemingskamer inzake Xeikon, kort gezegd wegens vormverzuim door de Ondernemingskamer.

De Ondernemingskamer zal opnieuw moeten beoordelen of zich wanbeleid heeft voorgedaan bij Xeikon met betrekking tot een tweetal feitelijke kwesties en wie daar (eventueel) voor verantwoordelijk zijn. In deze bijdrage wordt louter ingegaan op de procesrechtelijke problematiek die de inzet vormt van het beroep in cassatie. ${ }^{4}$ Alleen voor zover daarvoor van belang wordt hieronder ingegaan op de feiten. Daarover eerst het volgende.

Mr. T. Drenth is advocaat bij Clifford Chance te Amsterdam.

1. HR 19 juli 2019, ECLI:NL:HR:2019:1279. De beschikking van de Hoge Raad volgt op drie conclusies van 29 maart 2019 van A-G Timmerman in de zaken 18/02407, 18/01935 en 18/01950, waarvan de conclusie inzake $18 / 01935$ het meest relevant is voor de in deze bijdrage te behandelen onderwerpen (zie voor de conclusies van 29 maart 2019 van A-G Timmerman ECLI:NL:PHR:2019:363, ECLI:NL:PHR:2019:364 en ECLI:NL:PHR:2019:365).

2. Hof Amsterdam (OK) 6 februari 2018, ECLI:NL:GHAMS:2018:377, JOR 2018/94.

3. Hof Amsterdam (OK) 6 april 2018, ECLI:NL:GHAMS:2018:1609, ARO 2018/86.

4. Zie over de materiële problematiek de noot van Josephus Jitta onder de (toen nog niet verbeterde) tweede-fasebeschikking van 6 februari 2018 in JOR 2018/94 en de noot van Duynstee waar het de uitkoopprocedure inzake Xeikon betreft onder Hof Amsterdam (OK) 18 december 2018, ECLI:NL:GHAMS:2018:4684, JOR 2019/104 met noot onder JOR $2019 / 105$.
Recalcico Beheer B.V. (hierna: Recalcico, verzoekster) heeft de Ondernemingskamer bij verzoekschrift van 2 april 2014 verzocht een onderzoek te bevelen naar het beleid en de gang van zaken van Xeikon. Op 22 juli 2014 heeft de Ondernemingskamer een onderzoek gelast. ${ }^{5}$ Voor deze cassatieprocedure zijn twee verwijten relevant.

Allereerst het verwijt met betrekking tot de zogenoemde 'Upstreaming': Xeikon was in de relevante periode genoteerd aan Euronext Amsterdam. Punch International hield evenwel steeds een ruim meerderheidsbelang in Xeikon. In 2008 heeft Xeikon EUR 75 miljoen aan financiering aangetrokken. Onder de documentatie mocht Xeikon maximaal EUR 15 miljoen daarvan uitlenen (upstreamen) aan Punch International. Xeikon heeft vervolgens - in strijd met de leningsdocumentatie - EUR 45 miljoen aan Punch International uitgeleend. Punch International bleek daarop niet over voldoende liquide middelen te beschikken om deze 'Upstreaming' ongedaan te maken door het bedrag terug te betalen aan Xeikon.

Daarnaast het verwijt met betrekking tot de verwerving van het Accentis-belang: Punch International heeft nagenoeg alle aandelen verworven in het beursgenoteerde Accentis N.V. (hierna: Accentis). Kort daarna heeft de $\mathrm{RvC}$ van Xeikon ermee ingestemd dat Punch International haar schuld aan Xeikon zou voldoen door overdracht aan Xeikon van (1) aandelen Accentis en (2) een vordering van Punch International op Accentis. De koers van Accentis is na de overdracht aan Xeikon sterk gedaald en steeds aanzienlijk lager gebleven dan de prijs per aandeel die werd aangehouden bij de overdracht aan Xeikon.

Voor zover relevant was de verzoeker tot cassatie ten tijde van deze kwesties CFO van Xeikon (hierna: de CFO). In het dictum van haar tweede-fasebeschikking van 6 februari 2018 oordeelde de Ondernemingskamer dat de CFO met twee andere personen, de CEO van Xeikon en een commissaris, verantwoordelijk is voor het wanbeleid met betrekking tot de Upstreaming. Voorts bepaalde zij dat een drietal (andere)

5. Hof Amsterdam (OK) 22 juli 2014, ECLI:NL:GHAMS:2014:2899, ARO 2014/167. 


\section{Maandblad}

Ondernemingsrecht

commissarissen van Xeikon verantwoordelijk is voor het wanbeleid rondom de verwerving van het Accentis-belang.

R.o. 5.56 van de beschikking luidde, voor verbetering, als volgt (gecursiveerd steeds mijn toevoeging):

'De Ondernemingskamer acht [de CEO] en [de CFO] als bestuurders van Xeikon en [Commissaris $X$ ] als commissaris van Xeikon verantwoordelijk voor het wanbeleid ten aanzien van de Upstreaming en de verwerving van het Accentis Belang. De Ondernemingskamer verwijst naar hetgeen hierboven over deze onderwerpen en de rol van [de CEO], [de CFO] en [Commissaris X] is overwogen.'

Het dictum luidde, voor zover relevant en voor verbetering, als volgt:

'De Ondernemingskamer (...) stelt vast dat [de CEO], [de $C F O$ ] en [Commissaris $X$ ] verantwoordelijk zijn voor het vastgestelde wanbeleid met betrekking tot de Upstreaming; stelt vast dat [Commissarissen $A, B$ en $C$ ] verantwoordelijk zijn voor het vastgestelde wanbeleid met betrekking tot de verwerving van het Accentis Belang;'

Commissaris $\mathrm{C}$ verzocht de Ondernemingskamer vervolgens ex artikel 31 Wetboek van Burgerlijke Rechtsvordering (Rv) de beschikking te verbeteren, onder andere omdat in het hierboven weergegeven dictum zijns inziens ten onrechte niet werd vermeld dat ook een aantal andere bestuurders en commissarissen, onder wie de CFO en Commissaris X, verantwoordelijk zouden zijn voor de verwerving van het Accentisbelang, terwijl dit wel zou volgen uit de hierboven weergegeven rechtsoverweging in de beschikking.

Commissaris $\mathrm{X}$ concludeerde daarop tot afwijzing van het verzoek van Commissaris C. Hij deed vervolgens een zelfstandig artikel $31 \mathrm{Rv}$-verzoek om verwijderd te worden uit dezelfde rechtsoverweging van de beschikking waar Commissaris C zijn artikel $31 \mathrm{Rv}$-verzoek op baseerde (r.o. 5.56), voor zover die ertoe strekt dat hij verantwoordelijk was voor het wanbeleid ten aanzien van de verwerving van het Accentis-belang. Een en ander zodat deze overweging aan zou sluiten bij het dictum, waar hij immers op dit punt niet wordt genoemd als verantwoordelijke.

De Ondernemingskamer wees op 6 april 2018 een verbeteringsbeschikking. In deze beschikking overwoog de Ondernemingskamer onder andere dat van de CFO niet was vernomen; dat sprake was van een kennelijke fout die zich leent voor eenvoudig herstel (art. $31 \mathrm{Rv}$ ); dat zij het dictum aldus wijzigt dat de CFO en de CEO ook verantwoordelijk worden gehouden voor het vastgestelde wanbeleid met betrekking tot de verwerving van het Accentis-belang; en dat Commissaris X - per zijn verzoek - uit de bewuste rechtsoverweging (r.o. 5.56) wordt geschrapt voor zover het de verantwoordelijkheid voor de verwerving van het Accentis-belang betreft. ${ }^{6}$

De CFO stelde op 7 mei 2018 tijdig $^{7}$ beroep in cassatie in tegen zowel de beschikking als de verbeteringsbeschikking, hetgeen heeft geleid tot de hier te bespreken beschikking van de Hoge Raad.

In het onderstaande behandel ik drie onderwerpen die in deze zaak aan de orde kwamen:

1. de oproepingsproblematiek;

2. de reikwijdte van artikel $31 \mathrm{Rv}$; en

3. de reikwijdte van de vernietiging van de beschikking en de verbeteringsbeschikking.

\section{Oproepingsproblematiek}

De eerste onderdelen van het cassatiemiddel van de CFO klagen kort gezegd over de gebrekkige oproeping van de CFO in de tweede fase:

- De CFO had moeten worden opgeroepen nadat Recalcico in haar nadere schriftelijke reactie stelde dat de Upstreaming wanbeleid was. Voor zover in de tweede-fasebeschikking in dat kader in het midden is gelaten of sprake was van een vermeerdering van eis, was er in ieder geval sprake van een verandering van eis, hetgeen ook oproeping tot gevolg had moeten hebben.

- De Ondernemingskamer had de CFO in de tweede fase van de enquêteprocedure dienen op te roepen in overeenstemming met artikel $277 \mathrm{Rv}$.

\subsection{Oproeping na schriftelijke reactie Recalcico}

Artikel 130 lid 3 Rv bepaalt dat een verandering of vermeerdering van eis is uitgesloten tegen een partij die niet in het geding is verschenen, tenzij de eiser de verandering of vermeerdering tijdig bij exploot aan die partij kenbaar heeft gemaakt. Artikel $283 \mathrm{Rv}$ bepaalt dat artikel $130 \mathrm{Rv}$ van overeenkomstige toepassing is op de verandering of vermeerdering van een verzoek.

De Hoge Raad overweegt in de onderhavige beschikking dat dit voor een verzoekschriftprocedure (zoals de enquêteprocedure) meebrengt dat de rechter in elk geval alle in de procedure eerder opgeroepen maar niet-verschenen belanghebbenden opnieuw dient op te roepen, met opgave van de verandering of vermeerdering van het verzoek. ${ }^{8}$

De Hoge Raad overweegt vervolgens:

6. Verbeteringsbeschikking, r.o. 2.3.

7. De laatste dag van de driemaandentermijn ( 6 mei 2018; drie maanden na de tweede-fasebeschikking van 6 februari 2018) viel op een zondag; op grond van art. 1 lid 1 ATW was 7 mei 2018 dus de laatste dag van de (verlengde) termijn.

8. Zie eerder, maar in het kader van een alimentatiezaak, HR 10 juli 2009 ECLI:NL:HR:2009:BI3435, NJ 2009/359, r.o. 3.4.2, laatste zin. Zie ook Asser Procesrecht/Van Schaick 2 2016/179, met verwijzing naar bovenstaand arrest. 
'Als een van de partijen aan een of meer niet-verschenen belanghebbenden de verandering of de vermeerdering van het verzoek heeft meegedeeld, kan de rechter zich ook van zijn taak kwijten door zich ten aanzien van deze niet-verschenen belanghebbenden ervan te vergewissen dat die mededeling hen heeft bereikt. Ook in dat geval is immers recht gedaan aan de gedachte die aan art. 130 lid $3 \mathrm{Rv}$ ten grondslag ligt dat moet worden vermeden dat een belanghebbende een beslissing tegen zich moet laten gelden waarvan hij niet weet en niet kan weten dat en waarom deze is verzocht.' ${ }^{\prime}$

Bij de griffie van de Ondernemingskamer is navraag gedaan, waaruit volgt dat de CFO door de (griffie van de) Ondernemingskamer niet opnieuw is opgeroepen naar aanleiding van de verandering of vermeerdering van het verzoek. ${ }^{10}$ De Hoge Raad overweegt dat de Ondernemingskamer er ook niet van uit kon gaan dat de verandering of vermeerdering van het verzoek op andere wijze aan de CFO was meegedeeld. Interessant is daarbij nog dat de Hoge Raad overweegt dat de toezending van de nadere schriftelijke reactie aan de CFO door de advocaat van Recalcico niet de eigen verplichting van de Ondernemingskamer vervangt, temeer nu de CFO die nadere schriftelijke reactie niet heeft ontvangen. $\mathrm{Nu}$ de $\mathrm{CFO}$ daardoor geen gelegenheid voor verweer heeft gehad tegen het veranderde of vermeerderde verzoek, is dit in strijd met het in artikel 19 Rv neergelegde beginsel van hoor en wederhoor.

Deze overwegingen lijken mij juist en zijn in lijn met zowel het arrest van de Hoge Raad van 10 juli 2009 als recentere jurisprudentie van de Ondernemingskamer. ${ }^{11} \mathrm{Zij}$ bevestigen dat een dergelijke oproeping in een enquêteprocedure dus niet per exploot (zie immers de letterlijke tekst van art. 130 lid 3 $\mathrm{Rv}$ ) hoeft te geschieden, maar door hernieuwde oproeping door de rechter van de niet-verschenen belanghebbenden met opgave van de verandering of vermeerdering van het verzoek. ${ }^{12}$

\subsection{Oproeping tweede fase}

De derde afdeling van de derde titel Rv handelt over de oproeping van belanghebbenden. Artikel $272 \mathrm{Rv}$ schrijft voor dat de oproeping van niet in de procedure verschenen belanghebbenden van wie de woonplaats of het werkelijk verblijf onbekend is, geschiedt door plaatsing van de oproeping in de Staatscourant. De oproeping van overige niet in de procedure verschenen belanghebbenden geschiedt door de griffier bij aangetekende brief, tenzij de rechter anders bepaalt. Artikel $277 \mathrm{Rv}$

9. Beschikking, r.o. 5.1.2. De Hoge Raad verwijst hier nog naar NJ $2001 / 167$, r.o. 3.4 .2 , welke overweging handelt over de vraag of een procespartij ten processe wel of niet een bepaalde stelling had betrokken.

10. Zie r.o. 2.9 van de beschikking en tevens de conclusie van 29 maart 2019 van A-G Timmerman, ECLI:NL:PHR:2019:364, onder 2.17.

11. Zie bijv. Hof Amsterdam (OK) 3 april 2014, ECLI:NL:GHAMS: 2014:1168, ARO 2014/66, r.o. 4.1.

12. Zie eerder anders: J.H. Lemstra \& T. Salemink, Kroniek enquêterecht 2014, in: M. Holtzer, A.F.J.A. Leijten \& D.J. Oranje (red.), Geschriften vanwege de Vereniging Corporate Litigation 2014-2015 (VDHI nr. 128), Deventer: Wolters Kluwer 2015, p. 13. schrijft voor dat de oproeping bij brief van verzoekers of belanghebbenden die geen bekende woonplaats of bekend werkelijk verblijf in Nederland hebben, maar wel een bekende woonplaats of een bekend werkelijk verblijf in een staat waar de Betekeningsverordening van toepassing is, geschiedt door rechtstreekse verzending overeenkomstig artikel 14 van die verordening (aangetekend schrijven met ontvangstbevestiging of op gelijkwaardige wijze). ${ }^{13}$

In zowel de beschikking als de verbeteringsbeschikking wordt vermeld dat de CFO woont in Astene (België). De CFO woonde evenwel al sinds 2010 elders in België. De secretaris van de Ondernemingskamer heeft de CFO (1) louter bij gewone brief aan zijn oude adres opgeroepen voor de mondelinge behandeling van het tweede-faseverzoek op 13 april 2017, en (2) niet opgeroepen naar aanleiding van de nadere schriftelijke reactie van Recalcico van 23 februari 2017.

De Hoge Raad overweegt dat het gegeven dat de Ondernemingskamer niet aan de wettelijke oproepingsvereisten heeft voldaan, gekoppeld aan het gegeven dat de CFO niet in de procedure is verschenen, ertoe moet leiden dat ervan moet worden uitgegaan dat de CFO zich niet heeft kunnen verweren ter voorkoming van de vaststelling van wanbeleid en zijn verantwoordelijkheid daarvoor, hetgeen leidt tot een schending van de eisen van hoor en wederhoor. Ook dit onderdeel slaagt dus.

Dit heelt overigens ook de mogelijke niet-ontvankelijkheid van de CFO in cassatie. In de enquêteprocedure komt beroep in cassatie immers - in beginsel - alleen toe aan hen die in de vorige instantie zijn verschenen en die tegen het verzoek verweer hebben gevoerd. ${ }^{14}$ De tekst van artikel 426 lid $1 \mathrm{Rv}$ ('in een der vorige instantiën verschenen' ${ }^{15}$ ) heeft niet de strekking om beroep in cassatie uit te sluiten als de niet-verschenen belanghebbende 'buiten zijn schuld niet in de vorige instantie is verschenen', aldus de Hoge Raad. ${ }^{16}$ De CFO dient derhalve in zijn cassatieberoep te worden ontvangen.

De beschikking van de Hoge Raad heeft een bredere relevantie voor de oproeping van belanghebbenden in enquêteprocedu-

13. Verordening (EG) 1393/2007 van het Europees Parlement en de Raad van 13 november 2007 inzake de betekening en de kennisgeving in de lidstaten van gerechtelijke en buitengerechtelijke stukken in burgerlijke of in handelszaken (de betekening en de kennisgeving van stukken), art. 14: 'Elke lidstaat kan de betekening of kennisgeving van gerechtelijke stukken aan in een andere lidstaat verblijvende personen rechtstreeks door postdiensten doen verrichten bij aangetekend schrijven met ontvangstbevestiging of op gelijkwaardige wijze.'

14. Daarnaast komt de mogelijkheid van beroep in cassatie toe aan de rechtspersoon, ongeacht of deze bij de Ondernemingskamer is verschenen (art. 2:359 BW). Art. 2:359 BW derogeert overigens niet aan art. 426 lid $1 \mathrm{Rv}$, zie HR 10 januari 1990, ECLI:NL:PHR:1990:AC1234, NJ 1990/466, r.o. 3.3 .

15. Art. 426 lid $1 \mathrm{Rv}$ : 'Tegen beschikkingen op rekest kan beroep in cassatie worden ingesteld door degenen, die in een der vorige instantiën verschenen zijn, binnen drie maanden, te rekenen van de dag van de uitspraak.'

16. Zie de beschikking, r.o. 3.1. Zie eerder in gelijke zin: HR 7 december 2001, ECLI:NL:HR:2001:AD6831, NJ 2002/38, r.o. 4.2. 


\section{Maandblad \\ Ondernemingsrecht}

res waar de belanghebbende niet is verschenen (art. $272 \mathrm{Rv}$ ) en waar het belanghebbenden betreft die geen bekende woonplaats in Nederland hebben, maar wel in een staat waar de Betekeningsverordening van toepassing is (art. $277 \mathrm{Rv}$ ). Wat die laatste categorie betreft zij opgemerkt dat een substantieel deel van de enquêtebeschikkingen van de Ondernemingskamer enquêteprocedures betreft waar één of meer bij de vennootschap betrokken partijen woonplaats hebben in het buitenland. ${ }^{17}$ Het is daarbij de vraag of belanghebbenden in andere zaken tot op heden wél correct zijn opgeroepen. Voor aanhangige en toekomstige enquêteprocedures geldt dat oproeping voortaan correct zal moeten geschieden om latere aantasting van beschikkingen te voorkomen.

\section{Reikwijdte artikel 31 rv}

Artikel $31 \mathrm{Rv}$ voorziet in de mogelijkheid van herstel van 'kennelijke fouten'. Het criterium voor de toepassing van artikel $31 \mathrm{Rv}$ is of voor partijen en derden direct duidelijk is dat van een vergissing sprake is. De fout moet met andere woorden, mede in het licht van de stellingen van partijen, niet voor redelijke twijfel vatbaar zijn en voor derden op het eerste gezicht duidelijk zijn. ${ }^{18}$ Tegen verbetering ex artikel $31 \mathrm{Rv}$ staat geen voorziening open (art. 31 lid $4 \mathrm{Rv}$ ). Wél staat een voorziening open indien wordt aangevoerd dat de rechter buiten het toepassingsgebied van artikel $31 \mathrm{Rv}$ is getreden.

In dit geval waren er als genoemd twee, deels tegenstrijdige, artikel $31 \mathrm{Rv}$-verzoeken: (1) het verzoek van Commissaris C dat in het dictum ten onrechte niet werd vermeld dat de CFO, de CEO en Commissaris X verantwoordelijk zouden zijn voor de verwerving van het Accentis-belang, terwijl dit wel volgt uit een eerdere overweging (r.o. 5.56) in de beschikking, en (2) het verzoek van Commissaris $\mathrm{X}$ om die overweging juist zo aan te passen dat hij daar niet langer in voorkwam.

In de verbeteringsbeschikking wordt vervolgens beslist dat de $\mathrm{CFO}$ en de $\mathrm{CEO}$ in het dictum ook verantwoordelijk zijn voor het vastgestelde wanbeleid met betrekking tot de verwerving van het Accentis-belang, en dat Commissaris $\mathrm{X}$ dat juist niet is. ${ }^{19}$ De Ondernemingskamer had in de oorspronkelijke beschikking een aantal overwegingen gewijd aan de verwerving van het Accentis-belang (r.o. 5.16-5.27). In het licht van die overwegingen zijn de verbeteringen feitelijk niet onbegrijpelijk. De vraag is evenwel of sprake is van een kennelijke fout die zich leent voor herstel ex artikel $31 \mathrm{Rv}$. Daarbij is het probleem erin gelegen dat 'niet duidelijk [blijkt] of datgene wat de ondernemingskamer heeft bedoeld te beslissen over de verantwoordelijkheid voor het wanbeleid bij de verwerving van het Accentis Belang, in rov. 5.56 staat of in het dictum, dan wel in geen van beide', aldus de Hoge Raad. Dit is feitelijk juist: uit

17. Zie o.a. H-J. de Kluiver, Over Delaware, de Ondernemingskamer en de aantrekkelijkheid van Nederland als vestigingsland, in: G. Solinge e.a. (red.), Nederland, het Delaware van Europa? (VDHI nr. 135), Deventer: Wolters Kluwer 2016, p. 150 e.v.

18. Zie Kamerstukken II 1999/2000, 26855, 3, p. 62 en 63 (MvT).

19. Zie de verbeteringsbeschikking, r.o. 2.3. r.o. 5.16-5.27 volgt immers niet zonder meer wie volgens de Ondernemingskamer verantwoordelijk zijn voor het wanbeleid bij de verwerving van het Accentis-belang.

Vervolgens overweegt de Hoge Raad dat het feit dat hierover debat mogelijk is, blijkt uit de deels tegenstrijdige herstelverzoeken. ${ }^{20}$ Dit is juist, al lijkt de - terechte - constatering dat er objectief debat over mogelijk is in dit geval belangrijker dan het bestaan van de deels tegenstrijdige herstelverzoeken in deze zaak. De door partijen gewenste wijzigingen zeggen wellicht minder over hun daadwerkelijke opvattingen over - en begrip van - de beschikking en eventuele daarin besloten liggende kennelijke fouten dan over de persoonlijke belangen bij de respectievelijke verzochte (deels tegenstrijdige) wijzigingen. In ieder geval heeft er te gelden dat er in dit geval duidelijk discussie mogelijk was. Van een kennelijke fout in de zin van artikel $31 \mathrm{Rv}$ was dan ook geen sprake. ${ }^{21}$ De Hoge Raad oordeelt mijns inziens terecht dat de Ondernemingskamer buiten het toepassingsgebied van artikel $31 \mathrm{Rv}$ is getreden. Daardoor wordt het rechtsmiddelenverbod van artikel 31 lid $4 \mathrm{Rv}$ doorbroken.

In zijn conclusie overweegt A-G Timmerman hierover nog het volgende:

'Een tegenstrijdigheid tussen de overwegingen van de beschikking en het dictum kan duiden op het bestaan van een kennelijke fout die zich leent voor eenvoudig herstel (nr. 3.31 hiervoor). Deze situatie zou zich hebben voorgedaan als de ondernemingskamer het dictum in overeenstemming had gebracht met rov. 5.56 overeenkomstig het verzoek van $[$ Commissaris $\mathrm{C}] .($...)

Bij de tegenstrijdigheid tussen rov. 5.56 en het dictum van de beschikking is mijns inziens voor partijen en derden direct duidelijk dat sprake is van een vergissing, dat geldt mijns inziens echter niet voor de tegenstrijdigheid die de ondernemingskamer signaleert tussen rov. 5.16-5.27 en rov. 5.56. Het is gelet daarop voor partijen en derden mijns inziens niet direct duidelijk waar - in het dictum of in het lichaam - de ondernemingskamer steekjes heeft laten vallen. ${ }^{22}$

Ik ben het eens met A-G Timmerman dat de aanvullende tegenstrijdigheid tussen r.o. 5.16-5.27 en r.o. 5.56 tot te veel onduidelijkheid leidt, terwijl een tegenstrijdigheid tussen louter het dictum en r.o. 5.56 mogelijk wel een kennelijke fout zou hebben opgeleverd die zich zou lenen voor eenvoudig herstel. Toch roept dit de vraag op of er - gezien de terechte hoge lat van artikel $31 \mathrm{Rv}$ - ook in dat geval niet alsnog enig debat

20. Zie in gelijke zin: A-G Timmerman in zijn conclusie van 29 maart 2019 , ECLI:NL:PHR:2019:364, onder 3.37.

21. Zie o.a. Korsten-Krijnen/Ten Kate \& Wesseling-van Gent, Herroeping, verbetering en aanvulling van burgerrechterlijke uitspraken (BPP nr. 5), Deventer: Kluwer 2013/II.3.4.

22. Conclusie van 29 maart 2019 van A-G Timmerman, ECLI:NL:PHR: 2019:364, onder 3.35-3.37. 
mogelijk zou zijn over waar de kennelijke fout dan in zou zijn gelegen (in het dictum of in r.o. 5.56?).

Het is evident dat die interpretatie grote gevolgen heeft. De uitleg dat de CFO bij wege van een kennelijke fout in het dictum zou ontbreken, zou immers betekenen dat hij geacht zou moeten worden al met deze (mogelijke toekomstige) verbetering rekening te houden. Hij had dan dus bijvoorbeeld onmiddellijk moeten beoordelen of hij had willen appelleren tegen de beschikking zoals deze had moeten luiden, dus met gewijzigd - aangevuld - dictum, ${ }^{23}$ en dat terwijl de CFO in het dictum nergens wordt vermeld voor wat betreft de verwerving van het Accentis-belang. In dat dictum valt overigens ook te lezen dat de Ondernemingskamer 'hetgeen meer of anders is verzocht [afwijst]', hetgeen voor de belanghebbende toch enig houvast zou moeten kunnen bieden dat er niet meer is toegewezen dan hetgeen in het dictum is opgenomen. ${ }^{24}$

Een tweede middelonderdeel klaagde nog dat de CFO de gelegenheid had moeten worden geboden om zich uit te laten over de verbetering (art. 31 lid 1 Rv). Ook dit middel slaagt; nu de CFO die gelegenheid niet is geboden, is het beginsel van hoor en wederhoor ook in dit opzicht jegens de CFO geschonden. ${ }^{25}$

\section{Reikwijdte vernietiging}

De Hoge Raad bepaalt dat de vernietiging van de tweede-fasebeschikking en van de verbeteringsbeschikking slechts betrekking heeft op de oordelen over het gestelde wanbeleid bij de Upstreaming en de verwerving van het Accentis-belang in 2008 en de verantwoordelijkheid daarvoor. De vernietiging bestrijkt dus niet het oordeel van de Ondernemingskamer over de gebeurtenissen die hebben plaatsgevonden 'in de periode na 2008, waarbij [de CFO] niet was betrokken'.

De Ondernemingskamer moet dus opnieuw beoordelen of zich bij de Upstreaming en de verwerving van het Accentisbelang in 2008 wanbeleid heeft voorgedaan en - uiteraard: eventueel - wie daarvoor verantwoordelijk zijn. De Ondernemingskamer moet daarover een voor alle partijen en belanghebbenden bindend oordeel geven. In die beoordeling zal de Ondernemingskamer nu ook de stellingen van de CFO en de eventuele reacties daarop van de andere partijen en belanghebbenden moeten betrekken. Het oordeel van wanbeleid zal daarmee dus ook anders kunnen uitvallen ten aanzien van de andere partijen. Dit is een juist gevolg. Gezien de overwegingen daaromtrent in de tweede-fasebeschikking, ${ }^{26}$ die steunen

23. Zie hieromtrent tevens Asser Procesrecht/Van Schaick 2 2016/111.

24. Ik merk overigens geheel ten overvloede op - in het kader van het criterium dat voor 'partijen en derden direct duidelijk is dat van een vergissing sprake is' - dat in de mij bekende annotaties van en wenken bij de (oorspronkelijke) beschikking van de Ondernemingskamer nergens wordt opgemerkt dat de CFO in het dictum niet voorkwam waar het de verantwoordelijkheid betrof voor het vastgestelde wanbeleid met betrekking tot de verwerving van het Accentis-belang.

25. Beschikking, r.o. 5.3.3.

26. Hof Amsterdam (OK) 6 februari 2018, ECLI:NL:GHAMS:2018:377, JOR 2018/94, r.o. 5.10-5.15 (over de Upstreaming) en r.o. 5.16-5.27 (over de verwerving van het Accentis-belang). op een kritisch onderzoeksverslag, is het echter de vraag of dat tot een materieel andere uitkomst zal leiden.

De Hoge Raad kiest met een partiële vernietiging van de beschikkingen voor een vanuit het oogpunt van de proceseconomie efficiënte benadering. Dit is tegenwoordig het uitgangspunt. ${ }^{27}$ In Xeikon was sprake van vormverzuim door de Ondernemingskamer. Voorheen werd aangenomen dat bij vernietiging wegens vormverzuim de geldigheid van de gehele bestreden uitspraak werd aangetast. ${ }^{28}$ Ook nu is dat soms nog het geval, zoals bij Meavita, waar het specifieke (uitzonderlijke) vormverzuim de gehele beschikking moest aantasten. ${ }^{29}$

Korthals Altes en Groen schrijven in dit kader dat 'beslissend is of, indien het vormvoorschrift wél in acht was genomen, de uitspraak in tegengestelde zin zou kunnen zijn uitgevallen; is dat het geval, dan is een algehele vernietiging op haar plaats' ${ }^{30}$ In dit geval is mijns inziens terecht geoordeeld dat het vormverzuim in deze zaak niet hoeft te leiden tot gehele vernietiging van de tweede-fasebeschikking en de verbeteringsbeschikking. Het oordeel wanbeleid en de verantwoordelijkheid daarvoor waar het gebeurtenissen van 2013 betreft, ${ }^{31}$ zouden niet anders hebben geluid indien de CFO wel correct was opgeroepen. Dat geldt (mogelijk) wel waar het de gebeurtenissen van 2008 (de Upstreaming en de verwerving van het Accentisbelang) betreft. ${ }^{32}$

Naast het beroep in cassatie van de CFO in zaak 18/01935 was ook principaal cassatieberoep ingesteld door een aantal andere functionarissen van Xeikon (in de zaak 18/0150). ${ }^{33}$ Dit was gericht tegen het oordeel van de Ondernemingskamer in de hierboven besproken r.o. 5.16-5.27 over de verwerving van het Accentis-belang. De klachten van dat onderdeel blijven buiten beschouwing vanwege de reikwijdte van de vernietiging, die gevolgen heeft voor alle partijen en belanghebbenden.

De vernietiging van de beschikking en van de verbeteringsbeschikking roept daarnaast nog een laatste vraag op, en dat is

27. Zie hierover Asser Procesrecht/Korthals Altes \& Groen 7 2015/296 en 331 ('Bij de beantwoording van deze vraag moet uitgangspunt zijn dat het cassatieberoep slechts "partiële werking" heeft').

28. Asser Procesrecht/Korthals Altes \& Groen 7 2015/296 met verwijzing naar A-G Wijnveldt bij HR 22 december 1938, ECLI:NL:HR:1938:37, NJ $1939 / 754$.

29. Omdat de beschikking in strijd met art. 5 lid 2 en 3 jo. art. 66 lid 2 Wet $\mathrm{RO}$ niet was gewezen door het in de wet bepaalde aantal rechters, hetgeen volgens de Hoge Raad meebracht dat 'de zaak volledig opnieuw moet worden beoordeeld’. HR 18 november 2016, ECLI:NL:HR:2016:2607, JOR 2017/30 (Meavita), r.o. 3.4.

30. Asser Procesrecht/Korthals Altes \& Groen 7 2015/296 met verwijzing naar HR 20 juni 1979, ECLI:NL:HR:1979:AD5646, NJ 1979/566 en HR 26 maart 1980, ECLI:NL:HR:1980:AC6854, NJ 1980/630.

31. Die in deze bijdrage niet aan de orde zijn gekomen, maar wel onderwerp vormden van de tweede-fasebeschikking.

32. Zie hierover ook de conclusie van 29 maart 2019 van A-G Timmerman, ECLI:NL:PHR:2019:365, onder 3.10-3.14.

33. Daarnaast was in die zaak ook voorwaardelijk incidenteel cassatieberoep ingesteld door Recalcico en (deels voorwaardelijk) incidenteel cassatieberoep ingesteld door Commissaris $\mathrm{X}$. 


\section{Maandblad \\ Ondernemingsrecht}

wat de relevantie hiervan is voor de uitkoopprocedure inzake Xeikon. In Xeikon heeft de Ondernemingskamer de enquêteen de uitkoopprocedure samengetrokken, mede omdat de uitkomst van de enquêteprocedure van belang zou zijn voor de uitkoopprocedure. ${ }^{34} \mathrm{Zij}$ heeft daarbij overwogen dat de inhoud van de verbeteringsbeschikking betrokken dient te worden bij de vaststelling van de uitkoopprijs. ${ }^{35}$ In het tussenarrest in de uitkoopprocedure gaat de Ondernemingskamer dan ook uitvoerig in op haar overwegingen in de thans (partieel) vernietigde verbeteringsbeschikking, waaronder op de 'verbeterde' r.o. 5.56. ${ }^{36}$ Mede op grond van deze overwegingen (die voor een groot deel zagen op de verwijten met betrekking tot de Upstreaming en de verwerving van het Accentis-belang) heeft de Ondernemingskamer de deskundige de volgende opdracht meegegeven:

'Alles afwegende schat de Ondernemingskamer dat op de peildatum van 31 januari 2014 tot het vermogen van Xeikon behoorden vorderingen op derden tot vergoeding van door haar geleden schade en dat de waarde van die vorderingen toen (ten minste) $€ 30$ miljoen bedroeg. De Ondernemingskamer zal de door haar te benoemen deskundige daarom opdragen bij de waardering van de aandelen uit te gaan van het bestaan van bedoelde vorderingen met een waarde van $€ 30$ miljoen.' 37

Een en ander roept de vraag op in hoeverre er nog een grond bestaat voor deze en andere overwegingen uit het uitkooparrest. Volgens de rol stond de uitkoopprocedure (na enkele aanhoudingen) voor deskundigenbericht op 24 september 2019. $\mathrm{Na}$ deze beschikking is het deskundigenbericht op die roldatum vervolgens voor een vijfde maal aangehouden, nu tot 19 november $2019 .{ }^{38}$ Het is daarmee de vraag of de beschikking van de Hoge Raad ook tot verdere vertraging in de uitkoopprocedure zal leiden, die overigens sinds 6 juni 2014 aanhangig is. ${ }^{39}$

\section{Conclusie}

Als gezegd heeft de beschikking van de Hoge Raad een bredere relevantie voor de oproeping van belanghebbenden in enquêteprocedures. In dit geval was sprake van eenzelfde soort vormverzuim bij de oproeping voor (1) de tweede fase, (2) na de verandering of vermeerdering van het verzoek door Recalcico, en (3) in het kader van de verbetering ex artikel $31 \mathrm{Rv}$. Oproeping van belanghebbenden in enquêteprocedures zal

34. Zie uitgebreider de noot van Duynstee onder Hof Amsterdam (OK) 18 december 2018, ECLI:NL:GHAMS:2018:4684, JOR 2019/104, onder 11 e.v., en de noot van Josephus Jitta in Ondernemingsrecht $2019 / 42$.

35. Hof Amsterdam (OK) 18 december 2018, ECLI:NL:GHAMS: 2018:4684, JOR 2019/104, r.o. 2.15.

36. Hof Amsterdam (OK) 18 december 2018, ECLI:NL:GHAMS: 2018:4684, JOR 2019/104, r.o. 2.23.

37. Hof Amsterdam (OK) 18 december 2018, ECLI:NL:GHAMS: 2018:4684, JOR 2019/104, r.o. 2.28.

38. Rol geraadpleegd op 26 september 2019.

39. Hof Amsterdam (OK) 26 mei 2015, ECLI:NL:GHAMS:2015:2040, ARO 2015/150, r.o. 1.1 (voortaan) moeten geschieden conform de wettelijke bepalingen van Rechtsvordering (art. 272 en 277 lid 1 en 2 Rv en art. 283 jo. art. 130 lid $3 \mathrm{Rv}$ ).

Dat is terecht. Schending van deze vormvoorschriften kan leiden tot grote gevolgen voor niet-verschenen belanghebbenden. De voormalige CFO werd bij een (verbeterings)beschikking in de tweede fase alsnog door de Ondernemingskamer verantwoordelijk gehouden voor vastgesteld wanbeleid, (1) zonder rechtsgeldig opgeroepen te zijn voor de tweede fase van de enquête, (2) zonder te zijn opgeroepen na een verandering of vermeerdering van het verzoek door Recalcico, en (3) zonder gekend te zijn in de artikel $31 \mathrm{Rv}$-beslissing, bij wege waarvan hij nota bene in het dictum werd toegevoegd als zijnde verantwoordelijk voor het wanbeleid ter zake van de verwerving van het Accentis-belang.

In dat kader is relevant de in de literatuur al uitgebreid aan de orde gekomen discussie over het karakter van de enquêteprocedure. Die zal ik hier niet herhalen. Voor zover relevant zij opgemerkt dat, hoewel met een oordeel van wanbeleid de civielrechtelijke aansprakelijkheid uiteraard niet direct vaststaat, ${ }^{40}$ steeds sterker geldt dat 'de stap van de enquêteprocedure naar de aansprakelijkheidsprocedure (...) zonder moeite te maken [is]'. ${ }^{41}$ De voorzitter van de Ondernemingskamer heeft in datzelfde kader meermaals in soortgelijke bewoordingen overwogen dat 'de mogelijkheid om diegenen die verantwoordelijk zijn voor het beleid en gang van zaken van de rechtspersoon in de onderzoeksperiode in rechte aan te spreken tot vergoeding van schade (...) in het verlengde [ligt] van een van de doeleinden van het enquêterecht: het verkrijgen van opening van zaken en de vaststelling bij wie de verantwoordelijkheid berust voor mogelijk blijkend wanbeleid'. ${ }^{42}$

Tegen die achtergrond dienen de processuele waarborgen uit Rechtsvordering in de enquêteprocedure dan ook te worden bezien. ${ }^{43}$ Daaronder vallen de wettelijke vereisten voor oproeping van belanghebbenden (nog los van het steeds terugkerende dilemma of het voor bestuurders en commissarissen in voorkomende gevallen beter is om wel of niet daadwerkelijk als belanghebbende te verschijnen). De beschikking van de Hoge Raad is tegen die achtergrond dan ook positief te noemen.

40. Zie HR 10 januari 1990, ECLI:NL:HR:1990:AC1234, NJ 1990/466 (Ogem), r.o. 5, verduidelijkt in HR 8 april 2005, ECLI:NL:HR: 2005:AS5010, NJ 2006/443 (Laurus), r.o. 3.8 en 3.9.

41. G. van Solinge, Van wanbeleid naar aansprakelijkheid, in: G. van Solinge e.a. (red.), Aansprakelijkheid van bestuurders en commissarissen. Nadere terreinverkenning in een uitdijend rechtsgebied (VDHI nr. 140), Deventer: Wolters Kluwer 2017, p. 517.

42. Hof Amsterdam (Vz. OK) 12 december 2018, ECLI:NL:GHAMS: 2018:4681, ARO 2019/55, r.o. 2.8. Zie eerder o.a. Hof Amsterdam (Vz. OK) 28 juni 2016, ECLI:NL:GHAMS:2016:2765, ARO 2016/160, r.o. 2.3, en in soortgelijke zin: Hof Amsterdam (Vz. OK) 6 november 2013, ECLI:NL:GHAMS:2013:4745, ARO 2014/15, r.o. 2.4.

43. Zie daarover uitgebreider de conclusie van A-G Timmerman van 29 maart 2019 in de zaak 18/01935, ECLI:NL:PHR:2019:364, onder 3.4 . 